https://doi.org/10.30910/turkjans.448343

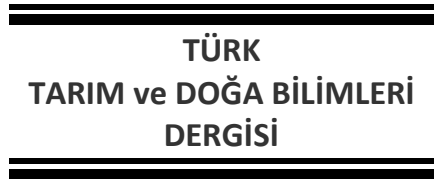

TÜRK

DERGISI

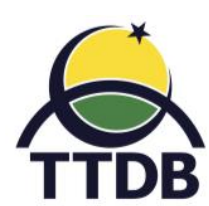

www.dergipark.gov.tr/turkjans

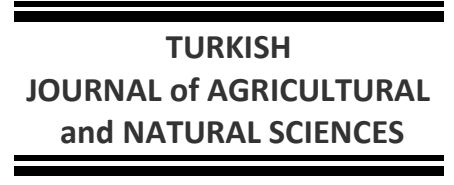

Araştırma Makalesi

\title{
Thiacloprid'in, Anadolu Bal Arısı (Apis mellifera anatoliaca) ve Kafkas Bal Arısı (Apis mellifera causica)'nın Yaşam Sürelerine Etkileri
}

\author{
Ahmed KARAHAN ${ }^{1 *}$, Mehmet Ali KUTLU ${ }^{2}$, İsmail KARACA ${ }^{3}$ \\ ${ }^{1}$ Çobanlar İlçe Gıda Tarım ve Hayvancılık Müdürlüğü, Afyonkarahisar, TÜRKiYE \\ ${ }^{2}$ Bingöl Üniversitesi, Veterinerlik Fakültesi, Klinik Öncesi Bilimleri Bölümü, Bingöl, TÜRKiYE \\ ${ }^{3}$ Süleyman Demirel Üniversitesi, Ziraat Fakültesi, Bitki Koruma Bölümü, Isparta, TÜRKiYE \\ *Sorumlu Yazar: ahmed.karahan@tarim.gov.tr
}

Geliş Tarihi: 07.03.2018

Düzeltme Geliş Tarihi: 22.05.2018

Kabul Tarihi: 26.05.2018

\section{Özet}

Son yıllarda tarımsal alanlarda, orman ve bahçelerde hastalık ve zararlılara karşı kullanılan pestisitlerin arılara verdiği zararlar gündeme geldikçe üreticiler ilaç tercihlerini arılara zarar vermeyen ilaçlar yönünde kullanmaya başlamışlardır. Thiacloprid, neonikotinoid bileşenler sınıfına ait dünya çapında yaygın olarak kullanılan bir pestisittir. Bu amaçla çalışmamızda thiacloprid etken maddeli insektisitin ülkemizde yaygın olarak bulunan Anadolu bal arısı (Apis mellifera anatoliaca) ve Kafkas arısının (Apis mellifera causica) yaşam süreleri üzerine etkileri araştırılmıştır. Çalışmada ele alınan insektisitin etiket dozu ( $40 \mathrm{ml} / 100 \mathrm{~L} \mathrm{su}$ ) ve bu dozdan $\% 50$ oranında seyreltilerek hazırlanan altı ayrı dozu ve kontrol grubu için su arılara püskürtülerek etkileri belirlenmiştir. Uygulama yapıldıktan sonra 12 saat aralıklarla denemeler kontrol edilmiş ve thiacloprid uygulanan arıların kontrol grubuna göre yaşam sürelerinde meydana gelen değişiklikler belirlenmiştir. En yüksek dozda insektisit uygulanan arıların tamamı 12 saat içinde ölürken kontrol grubu Anadolu arıları ortalama 16 gün, Kafkas arıları ortalama 15 gün yaşamıştır. Pestisit uygulanan arıların ortalama yaşam süresi Anadolu ve Kafkas bal arısında sırası ile 6 ve 5 gündür. Doz yaşam süresi arasındaki ilişki (Anadolu Arısında $R^{2}=0.9745$, Kafkas arısında $R^{2}=0,9439$ ) oldukça yüksek bulunmuştur. Kontrol grubu arılar pestisit püskürtülen arılara göre daha fazla yaşamışlardır. Kontrol grubuna göre ise pestisit uygulanan arıların yaşam sürelerindeki düşme oranı Anadolu arısında \%62.70 Kafkas arısında \%64.10 olarak belirlenmiştir.

Anahtar kelimeler: Apis mellifera anatoliaca, Apis mellifera causica, thiacloprid, arı ölümleri.

\section{Effects of Thiacloprid on the Life Span of Anatolian Honeybee (Apis mellifera anatoliaaca) and Caucasian Honeybee (Apis mellifera causica)}

\begin{abstract}
As the harm caused by pesticides in recent years has come up, conscious people prefer to use medicines that do not harm the pest. Thiacloprid active agricultural warfare agent from the Neonicotinoid group, which is one of the preferred pesticides for this purpose and has an increasing market size, was examined in this study, and its effect on the length of life of Anatolian honeybee (Apis mellifera anatoliaca) and Caucasian bee (Apis mellifera causica) was examined. In the study, the label dose of the pesticide ( $40 \mathrm{ml} / 100$-L-water) and 6 separate dose prepared by diluting $50 \%$ of the label dose were sprayed on the bees and their life span was monitored.. Only water is sprayed onto the control bees. Spray results were monitored every 12 hours and followed up to the day of death. The bees were fed with $2 \mathrm{M}$ sugared water and normal water during the time they lived. The change of the length of life of the control bees compared to the bees that were exposed to drugs with this method was identified. At the end of the study, all bees that received the highest dose dies within 12 hours while in the control group, the average was 16 days in Anatolian bees and 15 days in Caucasian bees. The average life span of bees sprayed with pesticide is 6 days in average Anatolia and 5 days in Caucasus. The relationship
\end{abstract}


between dose and the length of life was pretty high (In Anatolian Bee $R^{2}=0.9745$, In Caucasian Bee $R^{2}=0,9439$ ). The decay rate in the length of bees that received all pesticide doses were found $\% 62,70$ in Anatolian bees and \%64.10 in Caucasian bee compared to control group.

Key words: Apis mellifera anatoliaca, Apis mellifera causica, thiacloprid, honey bee deaths.

\section{Giriş}

Tarımsal alanlarda, orman veya bahçelerde hastalık ve zararlılara karşı kullanılan kimyasal pestisitlerin, çevreye, hedef dışı canlılara ve insanlara olan uzun süreli yıkıcı etkisine rağmen yine de en çok tercih edilen mücadele yöntemidir. Pestisitler doğanın dengesini bozduğu gibi, insanları ve diğer canlıları doğrudan veya dolaylı olarak etkilemekte, zararlı popülasyonlarını dengede tutan doğal düşmanların zarar görmesine de neden olmaktadır (Sarıtaş ve Ay, 2016). Neonicotinoid insektisitleri yer altı sularında, hedef dışı bitkilerde ve arı ürünlerinde tespit edilmiştir (Mogren ve Lundgren, 2016). Nektar ve polen alanlarındaki neonikotinoid kalıntıları, arı popülasyonlarının azalmasına neden olan potansiyel faktörlerden biri olarak gösterilmektedir (Pilling ve ark., 2013).

Günümüzde özellikle insanların sebep olduğu çevresel değişimlerden dolayı arılar, çok sayıda etmenin baskısı altında yaşamını sürdürmektedirler. Bitki çeşitliliğinin ve sayısının gün ve gün azalması, çevre kirliliği, kimyasallar, çeşitli hastalık ve diğer zararlılar arıların yaşamını olumsuz etkilen faktörlerin başında gelmektedir. Iklim değişikliği, gelecekte bu sorunların boyutunu ve etkisini daha da kötüleştirecektir (Goulson ve ark., 2015).

Pestisitler; arıları kontak, solunum ve mide zehiri olmak üzere üç yolla etkilemektedir (Yıldırım, 2012). En yaygın etki yolu, pestisitlerin tarımsal zararlılar ile mücadele amaçlı arazi koşullarında uygulandığı sırada yaşanmaktadır ki buna direkt temas denmektedir. Arılar, uygulama yapılan arazilerdeki çiçekli bitkileri ziyareti sırasında pestisitlerle temas ederler. Direk temas sonrası bu arılar kovanlarına döndüklerinde üzerlerinde bulunan pestisit kalıntılarını kovandaki diğer bireylere, larva ve yavru arılara da bulaştırmış olurlar (Özbek, 2010). Ayrıca arılar, pestisitlerle dolaylı yönlerden de temas ederler. İlaçlama sonrası bitki nektar ve polenlerinde ve yağmurlarla taşınan su birikintilerinde buluna pestisit kalıntıları arılara temas etmesiyle olur (Yıldırım, 2012).

Bal arılarında koloni kayıplarının artması dünya genelinde ekosistem, gıda güvenliği ve küresel ekonomi için oldukça ciddi bir tehdit oluşturmaktadır (Van der Zee ve ark., 2012; Van der Zee e ark., 2014; Chauzat ve ark., 2016). Bal üretiminin yanında bitkisel üretimde tozlaşma yoluyla sağladığı fayda ve ekonomik anlamda getirdiği gelir dünya çapında arıların ne kadar önemli olduğunu göstermektedir (Dag, 2009). Bu kadar büyük önem taşıyan bal arılarının son yıllarda yok olmaya başlaması ve bunun neden olacağı çevresel ve ekonomik sonuçlar birçok ülkede tartışılmaya başlanmıştır (Stokstad, 2007; VanEngelsdorp ve Meixner, 2010).

Arı popülasyonlarındaki düşüşlerin veya yok oluşların olası bir nedeni de pestisit kullanımıdır (Karahan ve ark., 2015; Phelps ve ark., 2017). Ayrıca koloni kaybı ve koloni sağlığını tehdit eden viruslar, Nosema ceranae ve Varroa destructor gibi hastalık ve zararlılarda bulunmaktadır (Muz ve Muz, 2017). Koloni kaybı nedenleri arasında; arıları strese sokan uygulamalar, arı biyolojisi ve koloni dinamiğinin yeterince bilinmemesi başta olmak üzere yetiştirici uygulamalarındaki hatalar, genetik varyasyonun azalması, parazit-predatör ve hastalık etmenlerinin yaygınlaşması, mevsim değişimleri, aşırı endüstriyel şeker kullanımı, cezp edici nitelikteki deterjanlar, aşırı akarisit ve antibiyotik kullanımı, tarımsal amaçlı kimyasal gübre kullanımları da bulunmaktadır (Kavak, 2016).

Tarımsal zararlıların mücadelesinde kullanılan insektisitlerin başında neonikotinoideler gelmektedir (Jeschke ve ark, 2011). Bu insektisitler 120 'den fazla ülkede ticari olarak kullanılmakta ve dünya pazarının yaklaşık üçte birini oluşturmaktadır (Simon-Delso ve ark., 2015; Renaud ve ark., 2018). Sistemik yapıya sahip olan neonicotinoidler suda çözünerek bitki tarafından alınır ve hedef dışı organizmalar tarafından tüketilir. Arıların besin olarak kullandığı nektar ve polene bulaşabilen (Godfray ve ark., 2014; Henry ve ark., 2015; Dively ve ark., 2015; Sanchez-Bayo ve ark., 2016) bu kimyasallar bal arısı (Apis mellifera L.) sağığını olumsuz yönde etkilemektedir (Wu-Smart ve Spivak, 2016).

Neonikotinoidler Koloni Kaybı Sendromunda doğrudan sorumlu olmasa bile, arıları Varroa destructor, Nosema apis ve diğer arı hastalık ve zararlılarına duyarlı hale getirerek dolaylı olarak etkilemektedir (Vidau ve ark., 2011; Cornman ve ark., 2012; Cressey, 2013). Peng ve ark., 2016; Decourtye ve ark., 2003). Neonikotinoid insektisitlerin sublethal dozlarına maruz kalan ergin ve larvalar, anormal davranışlar gösterirken koku alma ve öğrenme yeteneğinde de azalmaların olduğu belirlenmiştir.

Thiacloprid, böceklerin sinir sistemini etki eden neonikotinoid grubu bir insektisittir (Matsuda 
ve ark., 2005; Matsuda ve ark., 2009). Thiacloprid, meyve bahçelerinde ve sebzelerde yaprak biti ile mücadele yaygın olarak kullanılmasının yanında (Schuld, 2000) mısır ve bazı ürünlerde tohum kaplanmasında da kullanılmaktadır (Schmuck, 2001). Bu pestisitin arıların besin toplama davranışlarında, kovana dönme davranışında ve sosyal iletişimlerinde olumsuzluklara neden olduğu belirlenmiştir ( Tison ve ark., 2017).

Son yıllardaki arı popülasyonlarındaki azalma, bitki tozlaşmasında azalma anlamına geldiği için büyük endişe yaratmaktadır (Győri ve ark., 2017). Neonikotinoidlerin bu olumsuz duruma önemli katkısının olduğu düşünülmektedir (Long ve Krupke, 2016). Bu çalışmada ekosistemin önemli bir parçası olan arı popülasyonlarındaki azalmaya sebep olabilecek Neonicotinoid grubundan Thiacloprid etken maddeli insektisitin ülkemizde yaygın olarak bulunan Anadolu bal arısı (Apis mellifera anatoliaca) ve Kafkas arısının (Apis mellifera causica) yaşam süreleri üzerindeki etkisi incelenmiştir.

\section{Materyal ve Yöntem}

Çalışmamızda Anadolu bal arısı (Apis mellifera anatoliaca) ve Kafkas bal arısı (Apis mellifera causica) kullanılmıştır. Çalışma için uygulama yapılacak arıların belirlenmesi için Anadolu bal arısı ve Kafkas bal arısının bulunduğu arılıkların 10 metre önüne $2 \mathrm{M}^{\prime}$ lık şekerli su bulunan kaplar bırakılmıştır. Bu kaplara gelen bal arıları rastgele bir şekilde yakalanarak çalışma yapılacak laboratuvara getirilerek her birinde 5 adet birey olacak şekilde küçük gruplara ayrılmıştır. Gruplara ayrılan arılar, 2M'lık şurupla doyana kadar beslenmiş ve beslendikten 4 saat sonra uygulamalarda kullanılmıştır.

Thiacloprid'in normal ticari dozu $(40 \mathrm{ml} / 100$ L su) \%50 oranında saf su ile seyreltilerek altı ayrı dozu hazırlanmıştır $(40 \mathrm{ml} / 100 \mathrm{~L} \mathrm{su}, 20 \mathrm{ml} / 100 \mathrm{~L} \mathrm{su}$,

Çizelge 1. Thiacloprid uygulanan Anadolu (Apis mellifera anatoliaca) ve Kafkas bal arılarının (Apis mellifera causica) ortalama yaşam süreleri (ortalama tstandart hata).

\begin{tabular}{|c|c|c|c|c|}
\hline \multirow[b]{2}{*}{ Dozlar } & \multicolumn{4}{|c|}{ Ortalama yaşam süreleri } \\
\hline & $\begin{array}{c}\text { Anadolu bal arısı } \\
\text { (saat) }\end{array}$ & Gün & $\begin{array}{c}\text { Kafkas bal arısı } \\
\text { (saat) }\end{array}$ & Gün \\
\hline Kontrol (su) & $382.08 \pm 15.20 a^{*}$ & $16^{\mathrm{a}}$ & $351.52 \pm 13.95 a^{*}$ & $15^{\mathrm{a}}$ \\
\hline $1.25 \mathrm{ml} / 100 \mathrm{~L} \mathrm{su}$ & $336.00 \pm 15.97 a$ & 14 & $326.40 \pm 26.44 a$ & 14 \\
\hline $2.5 \mathrm{ml} / 100 \mathrm{~L} \mathrm{su}$ & $239.04 \pm 30.07 b$ & 10 & $225.60 \pm 9.41 b$ & 9 \\
\hline $5 \mathrm{ml} / 100 \mathrm{~L} \mathrm{su}$ & $155.04 \pm 20.43 c$ & 6 & $117.32 \pm 21.11 \mathrm{c}$ & 5 \\
\hline $10 \mathrm{ml} / 100 \mathrm{~L} \mathrm{su}$ & $87.84 \pm 9.28 \mathrm{~cd}$ & 4 & $57.12 \pm 7.33 \mathrm{~cd}$ & 2 \\
\hline $20 \mathrm{ml} / 100 \mathrm{~L} \mathrm{su}$ & $24.48 \pm 1.17 \mathrm{de}$ & 1 & $18.72 \pm 1.39 \mathrm{~d}$ & 1 \\
\hline $40 \mathrm{ml} / 100 \mathrm{~L} \mathrm{su}$ & $12.48 \pm 0.48 \mathrm{e}$ & $1 / 2$ & $12.00 \pm 0.00 \mathrm{~d}$ & $1 / 2$ \\
\hline
\end{tabular}

${ }^{a} 0.5$ den küçükler alt güne, 0.5 den büyükse üst güne tamamlanmıştır.

${ }^{*}$ Sütunlar yukarıdan aşağıya incelendiğinde aynı harf ile gösterilen ortalamalar Tukey $(P<0.05)$ testine göre istatistiki olarak farksızdır.
$10 \mathrm{ml} / 100 \mathrm{~L} \mathrm{su}, 5 \mathrm{ml} / 100 \mathrm{~L} \mathrm{su}, 2,5 \mathrm{ml} / 100 \mathrm{~L} \mathrm{su}, 1,25$ $\mathrm{ml} / 100$ L su). Hazırlanan bu dozlar arılara el püskürtme aleti ile uygulanmıştır. Kontrol arılarına sadece saf su uygulanmıştır. Püskürtme sonucunda arılar her 12 saatte bir öldüğü zamana kadar kontrol edilmiştir. Arılar yaşadıkları süre içerisinde $2 \mathrm{M}$ şekerli su ile beslenmişlerdir. Bu yöntem ile ilaca maruz kalan arıların kontrol grubu arılara göre yaşam sürelerinde nasıl bir değişikliğin olduğu belirlenmiştir. Çalışmada Anadolu ve Kafkas bal arıları için ayrı ayrı 5 deneme kurulmuş ve her denemede 35 arı kullanılmıştır. Her bir arı türü için 175 olmak üzere toplam 350 adet bal arısı kullanılmıştır. verilen arıların tepkileri regresyon analizleri ile ortaya konulmuştur. İstatistik analizlerde SPSS (ver. 17) programı yardımı ile tek yönlü varyans analizi kullanılmış olup, çoklu karşılaştırma testlerinden Tukey testinden yararlanılmıştır $(P<0.05)$.

\section{Bulgular ve Tartışma}

Thiaclopridin tarımsal mücadele amaçlı kullanılan (40 ml/100 L su) dozuna maruz kalan arıların büyük çoğunluğu ilk 12 saat içinde ölmüştür (Çizelge 1). Dozun azalmasına bağlı olarak arıların yaşam süreleri de artmıştır. Anadolu bal arısında en düşük doz olan $1.25 \mathrm{ml} / 100 \mathrm{~L}$ su ve kontrol grubu arılar istatistiki olarak aynı grupta yer almışlardır. Diğer tüm dozlar kontrol grubundan farklı istatistik grupta yer almışlardır. Kafkas bal arısında ise kontrol grubu arılar ile en düşük doz uygulanan arılar aynı istatistik grubu içine yer almış ve yaklaşık olarak aynı sürede ölmüşlerdir. Thiaclopridin ticari dozu (40 $\mathrm{ml} / 100 \mathrm{~L} \mathrm{su}$ ) ile bunun $\% 50$ seyreltilmiş hali olan 20 $\mathrm{ml} / 100 \mathrm{~L}$ su dozu istatistiksel olarak aynı grupta yer almış ve uygulama yapılan arılar 24 saat içinde ölmüştür.
Yapılan bu işlemin sonucunda farklı doz 
Çizelge 1'de pestisit uygulaması sonucu arıların ortalama yaşam süreleri ve Kontrol grubuna bağlı olarak istatistik grupları verilmiştir. Kontrol grubu arılar ve buna en yakın $1.25 \mathrm{ml} / 100 \mathrm{~L}$ su dozu uygulanan arılar istatistiki olarak aynı grupta yer almış ve çizelgede a harfi ile belirtilmiştir. Doz arttıkça Kontrol grubuna bağlı olarak istatistiki olarak ayrılan arılar diğer harfler ile belirtilmiş ve farklı bir grupta yer almıştır.

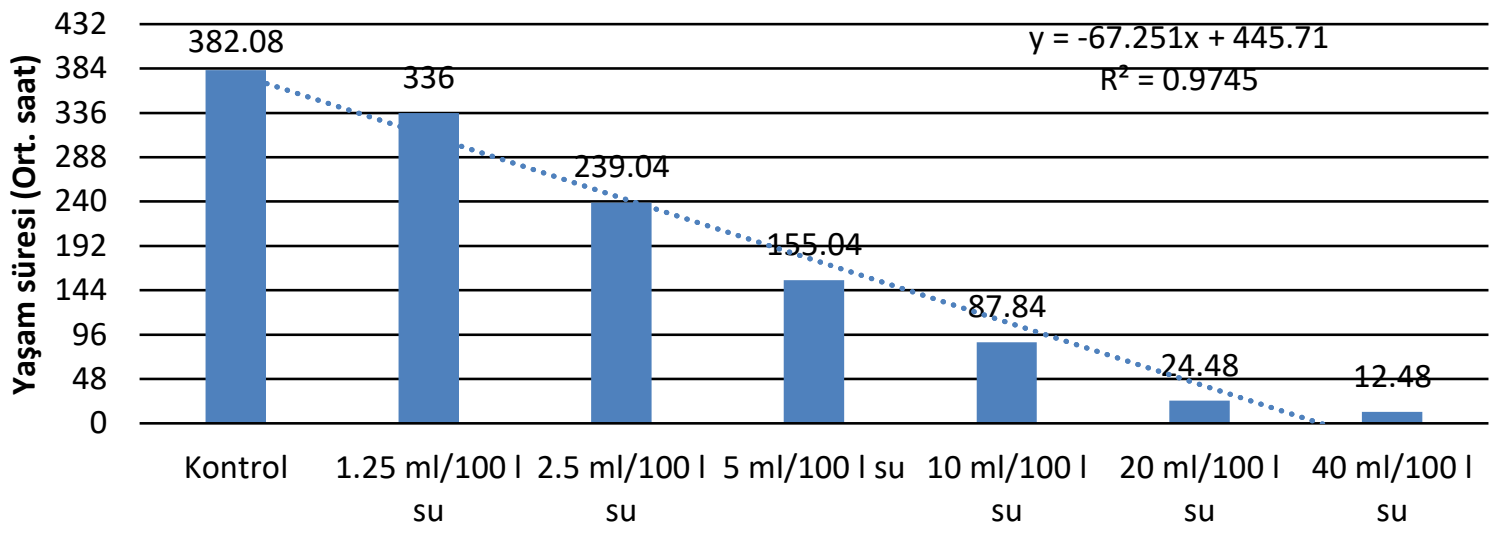

Uygulanan Doz Miktarları (1,25 ml/100L Su - 40 ml/100 L Su)

Şekil 1. Thiacloprid uygulanan Anadolu arılarının ortalama yaşam süresi ve regresyon grafiği.

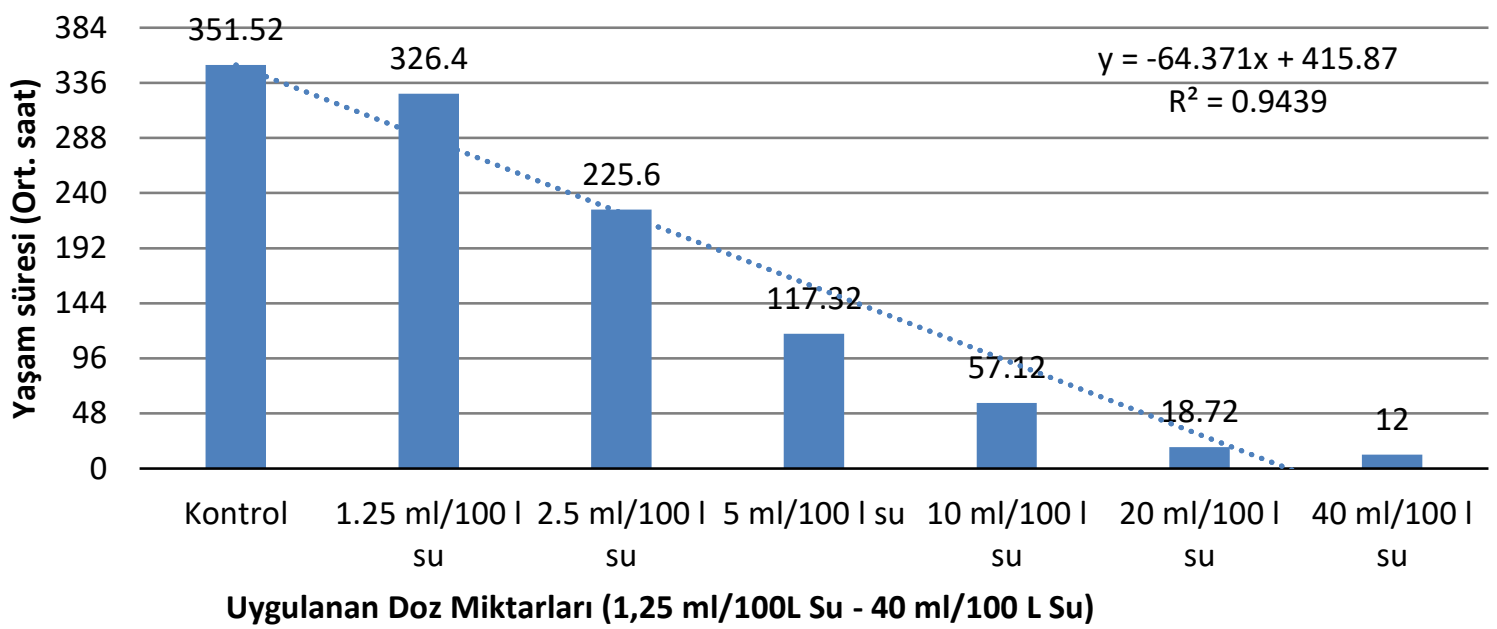

Şekil 2. Thiacloprid uygulanan Kafkas arılarının ortalama yaşam süresi ve regresyon grafiği.

Thiacloprid uygulanan arılarının doz - yaşam süresi arasındaki ilişkiler şekil 1 ve 2'de gösterildiği gibi uygulanan doz arttıkça yaşam süresinde azalma görülmüştür. Doz ile yaşam süresi aralarındaki ilişki oldukça yüksektir (Anadolu bal arısı: $R^{2}=0.9745$, Kafkas bal arısı: $\left.R^{2}=0.9439\right)$. Kontrol grubu arılara göre pestisit püskürtülen arıların yaşam sürelerindeki düşme yüzdesi şekil 3’de verilmiştir.
Şekil 3'de Kontrol grubu arılara göre pestisit püskürtülen arıların yaşam sürelerindeki düşme yüzdesi verilmiştir. Thiacloprid'in tarımsal mücadelede tavsiye edilen $40 \mathrm{ml} / 100 \mathrm{~L}$ su dozu uygulandıktan sonra arıların yaşam sürelerinde Anadolu bal arısında \%96.73, Kafkas bal arısında \%96.59 azalma olmuştur. Doz azaldıkça arıların yaşam süreleri de artmış fakat en düşük dozda bile yaşam sürelerinde düşme olmuştur. 


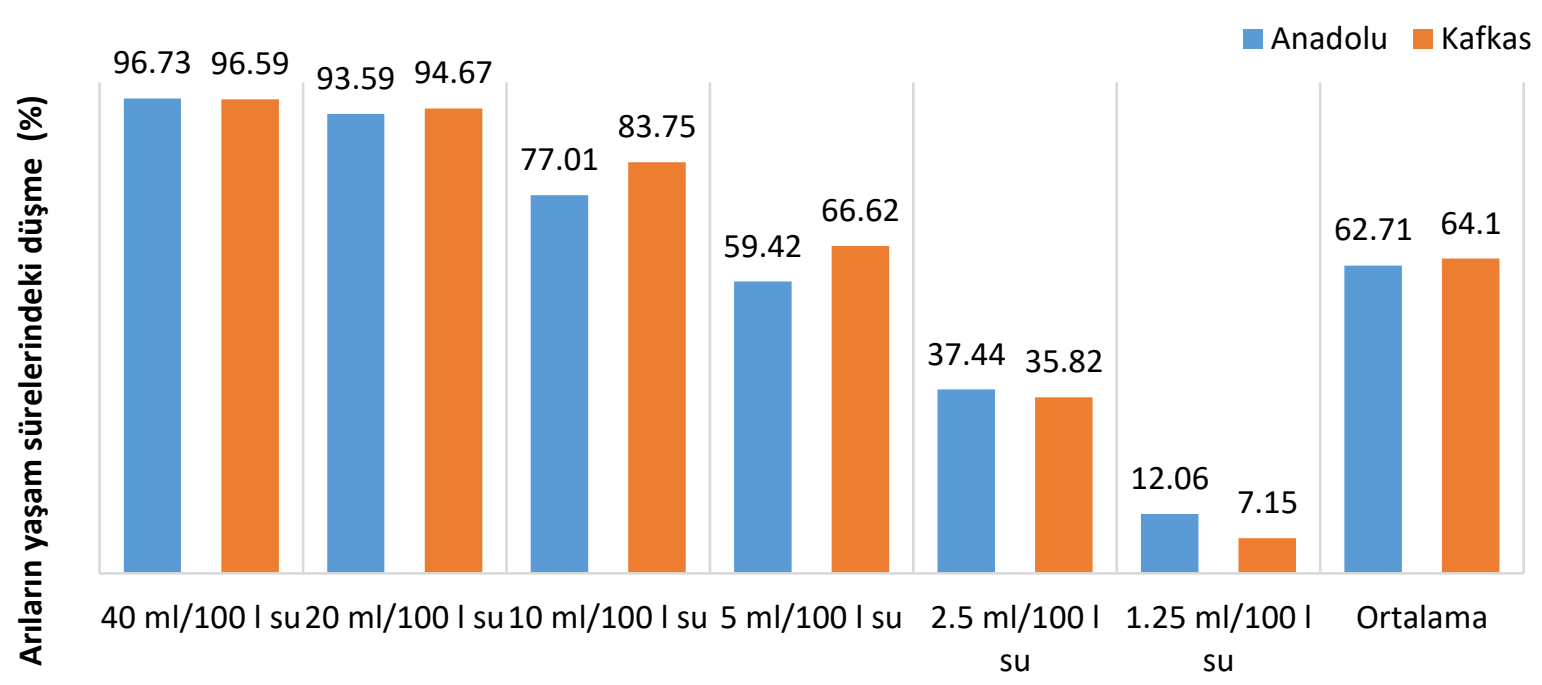

Uygulanan doz miktarları $(1,25 \mathrm{ml} / 100 \mathrm{~L} \mathrm{su}-40 \mathrm{ml} / 100 \mathrm{~L} \mathrm{su})$

Şekil 3. Thiacloprid uygulanan arıların yaşam süresindeki düşme yüzde (\%)'si.

\section{Sonuç ve Öneriler}

Son zamanlarda tarım ürünlerinde zararlılarla mücadele de aşırı ve bilinçsiz kullanılan kimyasal maddelerin zararlı etkisi kamuoyunda sık sık gündeme gelmektedir. Insanlar bu konuda bilinçlenmeye başlamış ve kimyasalların çevreye, hedef dışı canlılara ve insanlara olan uzun süreli yıkıcı etkisini konuşur olmuştur. Özellikle son zamanlarda arı ve yaban arılarının toplu ölüm sebebinin pestisitler olabileceğine dair birçok çalışma yapılmıştır (Ünal ve ark., 2010; Özbek, 2010; Karahan ve Karaca, 2016; Mitchell ve ark., 2017). Bu çalışma ile Neonicotinoid grubundan Thiacloprid etken maddeli insektisitin ülkemizde yaygın olarak bulunan Anadolu ve Kafkas bal arısının yaşam süreleri üzerindeki etkisi incelenmiştir. Çalışma sonucunda en yüksek doz püskürtülen arıların tamamı 12 saat içinde ölürken kontrol grubu arılar ortalama 15-16 gün arasında yaşadıkları belirlenmiştir. En düşük doza maruz kalan arıların yaşam süreleri kontrol grubu arılara yakın olduğu gözlenmiştir. Pestisit uygulanan arıların ortalama yaşam süresi ise Anadolu ve Kafkas bal arısında sırası ile 6 ve 5 gün olarak tespit edilmiştir. Doz yaşam süresi arasındaki ilişki oldukça yüksek bulunmuştur. Kontrol grubu arılar pestisit uygulaması yapılan arılara göre daha fazla yaşamışlardır. Kontrol grubuna göre insektisit uygulaması yapılan arıların yaşam sürelerindeki düşme oranı Anadolu bal arısında \%62.70 Kafkas bal arısında ise \%64.10 olduğu belirlenmiştir.

Thiacloprid düşük dozlarda uygulandığında bile arıların yaşam sürelerini etkilediği ve vücut hareketlerinde yavaşlama, titreme ve bazı organlarını kullanamama (kanat, bacak, anten) şeklinde olumsuzluklara neden olduğu gözlenmiştir. Thiacloprid'in öğrenme ve bellek işlevlerini bozarak bal arılarının yaşamında önemli bir risk oluşturduğu (Tison ve ark., 2017) ve besin alım süresini de düşürdüğü belirtilmiştir (Dickel ve ark., 2018). Thiacloprid'in tarım alanlarında yaygın olarak kullanılan dozu ile beslenen arıların hayatını devam ettirebilmesi için gerekli vücut fonksiyonlarını kullanamadığı görülmüştür.

Tarım alanlarında kullanılan pestisitler gün geçtikçe artmakta olup, bunlar içinde de en büyük oranı Neonikotinoid'ler oluşturmaktadır. Kullanılan bu pestisitler sistemik olup bitkilerin iletim demetleri ile kök, gövde, sürgün, çiçek ve nektarlarına taşınarak bitkide etkinliğini sürdürmektedir. Tarlacı arılar polen ve nektar toplama aşamasında bitkilerdeki pestisit kalıntılarını kovana taşımaktadır. Pestisit kalıntısı içeren nektar, polen ve propolis ile temas eden arı doğrudan etkilenmekte, kovana taşıdığı için kovandaki arılarında temas ve beslenmesi ile koloni popülasyonu da dolaylı olarak etkilemektedir (Özdemir, 2017).

Küresel tozlaşma azalması, habitat yok edilmesi, böcek öldürücü kullanım ve iklim değişikliği veya bu faktörlerin bir kombinasyonu sonucu (Pettis ve ark., 2012) sanayileşmiş ülkelerin tarım alanlarında tozlaştırıcılara ihtiyaç artmıştır (Brittain ve ark., 2010; Cresswell ve ark., 2012). Dünya nüfusundaki hızlı artış ile birlikte yeryüzündeki kısıtlı kaynakların aşırı ve bilinçsiz kullanımının sonucu doğanın dengesi bozulmakta bu da ekosistemdeki çeşitliliği ve tarım ekonomisini tehdit etmektedir (VanEngelsdorp ve Meixner, 2010). Böcekler, doğadaki yabani çiçeklerin ve kültür bitkilerinin önemli tozayıcılarıdır (Biesmeijer ve ark.,2006; Oliver ve ark., 2015; Sanchez-Bayo ve Goka, 2014). Pestisitler kültür bitkilerini korumak amacıyla kullanılmasına rağmen bazen hedef dışı 
böcekleri etkilemekte ve faydalı böceklerin zarar görmesine ve popülasyonlarının azalmasına neden olmaktadır (Gray ve Peterson, 2017).

Sonuç olarak, hem ekonomik hem de birçok bitkinin en önemli tozlaştırıcısı olarak ekosistemde önemli bir görev üstlenen arılar, tarımsal yetiştiricilikte kullanılan pestisitlerden etkilenmektedir. Bal arılarında pestisitlerden kaynaklanabilecek ölümleri önlemek veya azaltmak için hem arıcıları hem de arıların bulunduğu bölgelerdeki ilaçlama yapan halkın bilinçlendirilmesi ve daha kontrollü pestisit kullanımını teşvik edilmesi gerekir.

\section{Teşekkür}

Arılar üzerine çalışma yapmamda öncü olan Prof. Dr. John M. HRANITZ'e, çalışmanın yapımı sırasında bize yardım eden, Erol TOMAS, Mehmet Ali YETIM ve katkılarından dolayı Dr. Özlem GÜVEN'e Teşekkür ederiz.

*Bu çalışma, 45. Apimondia Uluslararası Arıcılık Kongresinde, İstanbul/Türkiye'de 29 Eylül-4 Ekim 2017'de sunulmuştur.

\section{Kaynaklar}

Biesmeijer, J.C., Roberts, S.P., Reemer, M., Ohlemüller, R., Edwards, M., Peeters, T., Settele, J. 2006. Parallel declines in pollinators and insect-pollinated plants in Britain and the Netherlands. Science, 313(5785): 351-354.

Brittain, C.A., Vighi, M., Bommarco, R., Settele, J., Potts, S.G. 2010. Impacts of a pesticide on pollinator species richness at different spatial scales. Basic Appl Ecol 11: 106-115.

Chauzat, M.P., Jacques, A., Laurent, M., Bougeard, S., Hendrikx, P., Ribière-Chabert, M. 2016. Risk indicators affecting honey bee colony survival in Europe: One year of surveillance. Apidologie, 47: 348-378.

Cornman, R.S., Tarpy, D.R., Chen, Y., Jeffreys, L., Lopez, D., Pettis, J.S., Evans, J.D. 2012. Pathogen webs in collapsing honey bee colonies. PLoS one, 7(8): e43562.

Cressey, D. 2013. Europe Debates Risk to Bees. Nature 496: 408.

Cresswell, J.E., Page, C.J., Uygun, M.B., Holmbergh, M., Li, Y., Wheeler, J.G., Laycock, I., Pook, C.J., De Ibarra, N.H., Smirnoff, N., Tyler, C.R. 2012. Differential sensitivity of honey bees and bumble bees to a dietary insecticide (imidacloprid). Zoology 115: 365-371.

Dag, A. 2009. Interaction between pollinators and crop plants: the Israeli experience. Isr. J. Plant Sci. 57: 231-242.

Decourtye, A., Lacassie, E., Pham-Delègue, M.H. 2003. Learning performances of honeybees
(Apis mellifera L) are differentially affected by imidacloprid according to the season. Pest Manage. Sci. 59: 269-278.

Dickel, F., Münch, D., Amdam, G.V., Mappes, J., Freitak, D. 2018. Increased survival of honeybees in the laboratory after simultaneous exposure to low doses of pesticides and bacteria. PLoS One, 13(1): e0191256.

Dively, G.P., Embrey, M.S., Kamel, A., Hawthorne, D.J., Pettis, J.S. 2015. Assessment of chronic sublethal effects of imidacloprid on honey bee colony health. PLoS One 10: e0118748.

Godfray, H.C.J., Blacquiere, T., Field, L.M., Hails, R.S., Petrokofsky, G., Potts, S.G., McLean, A.R. 2014. A restatement of the natural science evidence base concerning neonicotinoid insecticides and insect pollinators. In Proc. R. Soc. B (281(1786): 20140558). The Royal Society.

Goulson, D., Nicholls, E., Botías, C., Rotheray, E.L. 2015. Bee declines driven by combined stress from parasites, pesticides, and lack of flowers. Science 347: 1255957.

Gray, A., Peterson, M. 2017. Investigating honey bee colony losses from surveys of beekeepers. In Royal Statistical Society Conference, 4-7 September 2017, Glasgow.

Győri, J., Farkas, A., Stolyar, O., Székács, A., Mörtl, M., Vehovszky, Á. 2017. Inhibitory effects of four neonicotinoid active ingredients on acetylcholine esterase activity. Acta Biologica Hungarica, 68(4): 345-357.

Henry, M., Cerrutti, N., Aupinel, P., Decourtye, A., Gayrard, M., Odoux, J.F., Bretagnolle, V. 2015. Reconciling laboratory and field assessments of neonicotinoid toxicity to honeybees. In Proc. R. Soc. B (282(1819): 20152110). The Royal Society.

Jeschke, P., Nauen, R., Schindler, M., Elbert, A. 2011. Overview of the status and global strategy for neonicotinoids. J. Agric. Food. Chem. 59: 2897-2908.

Karahan, A., Çakmak, I., Hranitz, J.M., Karaca, I., Wells, H. 2015. Sublethal imidacloprid effects on honey bee flower choices when foraging. Ecotoxicology, 24(9): 2017-2025.

Karahan, A., Karaca, i. 2016. Adana ve Konya illerindeki arıcılık faaliyetleri ve koloni kayıpları. Süleyman Demirel Üniversitesi Fen Bilimleri Enstitüsü Dergisi, 20(2).

Kavak, G. 2016. Son yıllarda görülen koloni kayıpları ve muhtemel sebepleri. Uludağ Arıcılık Dergisi, 15(1): 33-40.

Long, E.Y., Krupke, C.H. 2016. Non-cultivated plants present a season-long route of pesticide exposure for honey bees. Nature 
Communications 7, Article number: 11629 doi:10.1038/ncomms11629.

Matsuda, K., Shimomura, M., Ihara, M., Akamatsu, M., Sattelle, D.B. 2005. Neonicotinoids show selective and diverse actions on their nicotinic receptor targets: electrophysiology, molecular biology, and receptor modeling studies. Biosci Biotechnol Biochem 69: 14421452.

Matsuda, K., Kanaoka, S., Akamatsu, M., Sattelle, D.B. 2009. Diverse actions and target-site selectivity of neonicotinoids: structural insights. Mol Pharmacol 76: 1-10.

Mitchell, E.A.D., Mulhauser, B., Mulot, M., Mutabazi, A., Glauser, G., Aebil, A. 2017. A worldwide survey of neonicotinoids in honey. Science 358(6359): 109-111.

Mogren, C.L., Lundgren, G.J. 2016. Neonicotinoidcontaminated pollinator strips adjacent to cropland reduce honey bee nutritional status. Scientific Reports 6, Article number: 29608(2016) doi:10.1038/srep29608.

Muz, D., Muz, M. 2017. Investigation of some pathogens "colony loss syndrome" resembled losses apiaries in Tekirdağ. Kocatepe Veteriner Dergisi 10(2017): 21-28.

Oliver, T.H., Isaac, N.J., August, T.A., Woodcock, B.A., Roy, D.B., Bullock, J.M. 2015. Declining resilience of ecosystem functions under biodiversity loss. Nature Communications, 6: 10122.

Özbek, H. 2010. Arılar ve insektisitler. Uludağ Arıcılık Dergisi Kasım 2010 / Uludag Bee Journal, 10(3): 85-95.

Özdemir, N. 2017. Neonikotinoid pestisitler ve arı sağlığına etkileri. Uludağ Arıcılık Dergisi, 17(1): 44-48.

Peng, Y.C., Yang, E.C. 2016. Sublethal Dosage of Imidacloprid Reduces the Microglomerular Density of Honey Bee Mushroom Bodies. Scientific Reports 6, Article number: 19298.

Pettis, J.S., Van Engelsdorp, D., Johnson, J., Dively, G. 2012. Pesticide exposure in honey bees results in increased levels of the gut pathogen Nosema. 99: 153-158.

Phelps, J.D., Strang, C.G., Gbylik-Sikorska, M., Sniegocki, T., Posyniak, A., Sherry, D.F. 2017. Imidacloprid slows the development of preference for rewarding food sources in bumblebees (Bombus impatiens). Ecotoxicology, 1-13.

Pilling, E., Campbell, P., Coulson, M., Ruddle, N., Tornier, I. 2013. A Four-year field program investigating long-term effects of repeated exposure of honey bee colonies to flowering crops treated with thiamethoxam. PLoS ONE 8(10):

e77193. https://doi.org/10.1371/journal.pone.0077 193.

Renaud, M., Akeju, T., Natal-da-Luz, T., Leston, S., Rosa, J., Ramos, F., Azevedo-Pereira, H.M. 2018. Effects of the neonicotinoids acetamiprid and thiacloprid in their commercial formulations on soil fauna. Chemosphere, 194: 85-93.

Sanchez-Bayo, F., Goka, K. 2014. Pesticide residues and bees-a risk assessment. Plos one, 9(4): e94482.

Sanchez-Bayo, F., Goulson, D., Pennacchio, F., Nazzi, F., Goka, K., Desneux, N. 2016. Are bee diseases linked to pesticides? A brief review. Environment international, 89: 7-11.

Sarıtaş, E., Ay, R. 2016. Panonychus ulmi (Koch) ve Neoseiulus californicus (Mc Gregor)'un üreme gücü ve yaşam sürelerine bazı pestisitlerin etkisi: hormoligosis. Türkiye Entomoloji Dergisi, 40(1), 97-106.

Schmuck, R. 2001. Ecotoxicological profile of the insecticide thiacloprid. Pflschutz Nachr. Bayer Engl Edn 54: 161-184.

Schuld, M., Schmuck, R. 2000. Ecotoxicology. Effects of thiacloprid, a new chloronicotinyl insecticide, on the egg parasitoid trichogramma cacaoeciae. 9: 197.

Simon-Delso, N., Amaral-Rogers, V., Belzunces, L.P., Bonmatin, J.M., Chagnon, M., Downs, C. 2015. Systemic insecticides (neonicotinoids and fipronil): trends, uses, mode of action and metabolites. Environmental Science and Pollution Research. 2015(22): 5-34. pmid:25233913.

Stokstad, E. 2007. The case of the empty hives. Science 316: 970-972.

Tison, L., Holtz, S., Adeoye, A., Kalkan, Ö., Irmisch, N.S., Lehmann, N,. Menzel, R. 2017. Effects of sublethal doses of thiacloprid and its formulation Calypso ${ }^{\circledR}$ on the learning and memory performance of honey bees. Journal of Experimental Biology, 220(20): 36953705.

Ünal, H.H., Oruç, H.H., Sezgin, A., Kabil, E. 2010. Türkiye'de 2006-2010 yılları arasında, bal arılarında görülen ölümler sonrasında tespit edilen pestisitler. Uludağ Arıcılık Dergisi Kasım 2010 / Uludag Bee Journal, 10(4): 119125.

Van der Zee, R., Pisa, L., Andonov, S., Brodschneider, R., Charrie're, J.D., Chlebo, R., Wilkins, S. 2012. Managed honey bee colony losses in Canada, China, Europe, Israel and Turkey, for the winters of 2008-9 and 2009-10. Journal of Apicultural Research, 51: 100-114.

Van der Zee, R., Brodschneider, R., Brusbardis, V., Charrie're, J.D., Chlebo, R., Coffey, M.F., 
Gray, A. 2014. Results of international standardized beekeeper surveys of colony losses for winter 2012-2013: Analysis of winter loss rates and mixed effects modelling of risk factors for winter. Journal of Apicultural Research, 53: 19-34.

Van Engelsdorp, D., Meixner, M.D. 2010. A historical review of managed honey bee populations in Europe and the United States and the factors that may affect them. Journal of Invertebrate Pathology 103: 80-95.

Vidau, C., Diogon, M., Aufauvre, J., Fontbonne, R., Viguès, B., Brunet, J.L., Belzunces, L.P. 2011. Exposure to sublethal doses of fipronil and thiacloprid highly increases mortality of honeybees previously infected by Nosema ceranae. PLoS one, 6(6): e21550.

Wu-Smart, J., Spivak, M. 2016. Sub-lethal effects of dietary neonicotinoid insecticide exposure on honey bee queen fecundity and colony development. Scientific Reports, 6: 32108.

Yıldırım, E. 2012. Tarımsal Zararlılarla Mücadele Yöntemleri ve illaçlar. 3. Baskı. Atatürk Üniversitesi Ziraat Fakültesi Yayınları No: 219, Ziraat Fakültesi Ofset Tesisi, Erzurum, $330 \mathrm{~s}$. 